\title{
Contents, Vol. 210, No. 5, 1996
}

Lütjen-Drecoll, E. Preface 249

Lütjen-Drecoll, E. Dedication 250

Drance, S.M. The Concept of Chronic Open-Angle Glaucoma: A Personal View 251

Anderson, D.R. Glaucoma, Capillaries and Pericytes. 1. Blood Flow Regulation 257

Anderson, D.R.; Davis, E.B. Glaucoma, Capillaries and Pericytes. 2. Identification and

Characterization of Retinal Pericytes in Culture 263

Ferrari-Dileo, G.; Davis, E.B.; Anderson, D.R. Glaucoma, Capillaries and Pericytes. 3. Peptide

Hormone Binding and Influence on Pericytes 269

Zschauer, A.O.A.; Davis, E.B.; Anderson, D.R. Glaucoma, Capillaries and Pericytes. 4. Beta-

Adrenergic Activation of Cultured Retinal Pericytes 276

Anderson, D.R.; Davis, E.B. Glaucoma, Capillaries and Pericytes. 5. Preliminary Evidence that

Carbon Dioxide Relaxes Pericyte Contractile Tone 280

Hayreh, S.S. Blood Supply of the Optic Nerve Head 285

Flügel-Koch, C; May, C.A.; Lütjen-Drecoll, E. Presence of a Contractile Cell Network in the Human Choroid 296

Hubbard, W.C.; Kee, C; Kaufman, P.L. Aceclidine Effects on Outflow Facility after Ciliary

Muscle Disinsertion 303

Osborne, N.N.; Chidlow, G.

Do Beta-Adrenoceptors and Serotonin 5-HT 1A Receptors Have Similar Functions in the Control of Intraocular Pressure in the Rabbit?

308

KARGER

E-Mail karger@karger.ch Fax+ 41613061234 http://www.karger.ch

(C) 1996S. KargerAG, Basel

The list of contents is available at:

http://www. karger. ch/journals/oph/ophcont.htm 